I denne spalten presenteres tidligere publiserte artikler, mange av dem fra Tidsskriftet.

Artiklene er utvalgt og blir introdusert av Ole Didrik Lærum.

\title{
Om å løpe fra eller til
}

\author{
Overdreven løping kan være direkte farlig, og likevel har jogging vært et utbredt fenomen \\ i en hel generasjon. Observasjonen at mange joggere ser triste ut reiser spørsmålet om det \\ er noe alvorlig de løper fra eller til? Det er et paradoks at mange setter sunnheten på spill for \\ å bli enda sunnere. Eller er det noe helt annet som foregår?
}

Spørsmålet om joggingens mysterier ble reist av Stephan Rössner allerede for over 30 år siden, men ennå er mye uoppklart. Godt støttet av sportsindustrien er jogging et utbredt fenomen. A kalle det folkevandring er et mildt uttrykk, for i virkeligheten er det en notorisk folkeløping. Mange løper langs bilveier, og føttene klasker taktfast mot asfalten. Spesialkonstruerte sko og klær hører til, og både akutte skader og uheldige langtidseffekter på bevegelsesapparatet er vanlige.

Allerede i 1980-årene tok Stephan Rössner opp dette fenomenet. Han er en internasjonal ekspert på livsstil, helse og ernæring og har foretatt viktig forskning på folks matvaner og overvekt. Han var i en årrekke professor i folks helseatferd på Karolinska Institutet i Stockholm, der han bygde opp en klinikk for utredning og behandling av fedme. Dessuten skrev han en rekke bøker om livsstil, mat og helse, inklusive flere kokebøker. Gjennom tallrike fjernsynsprogrammer og populærvitenskapelige artikler er han blitt en kjent person i svensk offentlighet. I tekstene viser han en utpreget sans for humor. Han er nå pensjonert og bruker tiden på sitt forfatterskap.

I denne artikkelen fra 1982, som nå vi trykker opp igjen, påpeker han at enkel og fredelig spasering gjør folk lykkelige, men når det utvikler seg til jogging, oppstår en rekke problemer. Selv om forandring av endorfinnivået kan gi velvære og en nesten rusliknende tilstand når joggeren kommer ut av dusjen etter løpeturen, er det fortsatt et åpent spørsmål om slik vaneløping bare er av det gode. Og Rössner vet hva han skriver om, for på bildet er han selv ute og løper.

\section{Ole Didrik Lærum}

ole.laerum@gades.uib.no

Ole Didrik Lærum (f. 1940) er professor (adj.) ved Københavns Universitet og professor emeritus ved Universitetet i Bergen

\section{Om joggning och dess vådor}

Stephan Rössner, docent, Gustav V forskningsinstitut, Fack, S -104 01 Stockholm 60. Nordisk Medicin 1982; 97: 293-4.

I Ordspråksboken 27: 12 står att läsa: «... de fåkunniga löpa åstad och får plikta därför». Den gammaltestamentlige författaren var omedveten om efterföljande generationers entusiasm för joggning, men hans profetia anses ändå av många ha gått i uppfyllelse. En översiktlig litteratursökning ger vid handen, att vetenskapliga undersökningar om joggningens vådor nu blivit talrika, och utmålar potentiella risker för flertalet av våra organsystem, möjligen med undantag för reproduktionsapparaten.

I South African Medical Journal hävdar professor Grant-Whyte med emfas att joggning utgör «ett avvikande beteende », liknar drogberoende, leder till en hög incidens av kronisk ortopedisk sjukdom och bidrar till att förklara den höga dödligheten i kardiovaskulär sjukdom i Sydafrika.
Risken att dö under joggning finns ju alltid, likaväl som man kan dö på sammanträde, i hissen eller under coitus. Frågan är bara om man dör på grund av en bakomliggande hjärtsjukdom eller på grund av själva joggningen. I USA räknar man nu med 25 miljoner joggare. Om man - såsom Koplan i JAMA 1979 - gör antagandet, att medeljoggaren i USA har ett kardiovaskulärt status som amerikaner i allmänhet, kommer 119 amerikaner att årligen falla döda ner under träningsrundan eller efterföljande dusch och påklädning. Koplan gör då antagandet att medeljoggaren hänger sig åt sin last 20 minuter tre gånger i veckan, och det förefaller ju inte oöverstigligt.

Entusiaster har å andra sidan tagit munnen väl full i avsikt att betona långdistanslöpningens värde. Av oklar anledning har spe- ciellt Marathonlöpningens $42 \mathrm{~km}$ ansetts särskilt värdefulla. Så här skrev Bässler 1978: «It is biologically impossible for atherosclerosis to progress in anyone capable of even walking the $42 \mathrm{~km}$ distance.» Det tog dock inte Noakes och medarbetare många månader att samla ihop åtminstone fyra fall av ihjälkörda joggare och visa att obduktionen av dem avslöjat avsevärda aterosklerotiska forändringar.

Att joggning kan ge skador på skelett och leder är välbekant. Joggarens glädje över att tillsammans med andra få hänge sig åt sina pedala drifter har givit upphov till en hel flora av motionstävlingar av typen «fun run». Från exotiska delar av världen rapporteras nu dödsfall i bl a värmeslag under sådana joggningsexcesser. Härutöver finns många andra komplikationer beskrivna vid 
joggning. Diarré och melena har tillskrivits den parasympatiska övervikten hos vältränade joggare (med puls ner emot 35 slag/ minut) eller gastrointestinal ischemi $i$ anslutning till langvarig joggning. Hematuri förekommer ofta efter marathonlopp och anses vara ett benignt tillstånd. Man diskuterar fortfarande huruvida tillståndet är uttryck för «pseudonefritis» eller beror på ett trauma mot blåsan. Dialyskrävande njursvikt efter långdistansjoggning har också beskrivits som ett uttryck för organpåverkan genom värmeslag.

Vidare har näthinneavlossning associerats med joggning och i vissa fall förvärrats av slik aktivitet. Bland psykosomatiska följder av joggning kan nämnas $\mathrm{s} \mathrm{k}$ «running anorexia», ett tillstånd, som uppstår när collegeflickor till varje pris skall hänga med sina vältränade pojkvänner på långa joggingturer. Tillståndet förbättras när joggningsaktiviteten på läkares inrådan inskränkes kraftigt.

Joggning på allmän väg är inte ofarligt. Inte nog med att man kan bli påkörd, man kan också träffas av spott, spe eller tomma ölburkar från argsinta bilister. Att springa i mörkret är speciellt farligt, för då kan man snubbla på vägen! Reflexmärken på skor eller kläder innebär ett visst skydd mot alltför närgångna kontakter med bilar. En sann joggare bör ej heller glömma bort att alltid vara med nödiga identifikationshandlingar försedd. Det har nämligen också beskrivits hur svårt det varit att hantera anonyma träningsoverallsklädda trafikolycksfall, som varit omöjliga att identifiera på akutmottagningarna. Om allt detta kan man alltså läsa i den vetenskapliga litteraturen.

\section{Annorlunda psyke?}

Bland alla andra förekommande uppslag till forskning på joggningsskadornas område skall här endast nämnas en undersökning, som analyserat personligheten hos de joggare som skadats.

Man fann då att de som skadats tedde sig något annorlunda i psyket än oskadade. Detta berodde dock bara på könsskillnader. Män skadade mest knän, kvinnor vrister. Den traumatiserande övergången från högklackade skor till gymnastikskor anses av författaren vara en sannolik orsak till kvinnornas skademönster. Som alla andra riktiga forskare understryker han vikten av att långtidsundersökningar utföres inom detta högangelägna område.

\section{Trist att jogga?}

Trots ovan relaterade fasor hänger sig uppenbarligen nu miljoner människor åt joggningen till gagn för skofabrikanter, sportklädesmånglare och i allra bästa fall dem själva. Men har joggarna något kul när de trampar på i sina spår?

Veisrub har gjort observationen, att löpare inte längre ser ut $i$ ansiktet som förr $i$ tiden. I joggningens barndom var löparna glada, leende medelåldersmän, som med glädje konstaterade att fötterna fortfarande bar dem. Allteftersom åren gått har bilden ändrats. Joggarna ser numera ledsna och sammanbitna ut. Alla nya fina japanska klockor gör det möjligt att beräkna tider, mellantider, relativ fart över land $\mathrm{m} \mathrm{m}$ under joggningens gång, och tävlingsmomentet har blivit en beklämmande viktig ingrediens. Men dessutom verkar joggarna att ha så tråkigt, för de ser inte längre glada ut när de springer.

Varför är det så? Är det tristessen över att nöta samma gamla parkgångar och asfaltsträk? Eller är det - som Veisrub spekulerar - tråkigt därfor att man under joggningen inte kan tänka sammanhängande? Några studier som talar för att joggning möjliggör höga, vackra och begåvade tankar föreligger inte. Däremot synes det vara klart visat att spatserturer föder sådana tankar. I det antika Athéns arkader, vid schweiziska sjöar och langs romantiska skogsvägar i Nya England har filosofer, vetenskapsmän och konstnärer under stillsamt spatserande producerat utkasten till många av sina mest begåvade alster. Spatserturen har förlorat anseende som fritidsnöje. Att spatsera utan att samtidigt utföra något nyttigt, såsom att valla hunden eller dra en barnvagn väcker uppmärksamhet eller leder misstankarna till en aggressiv form av claudicatio intermittens. Veisrub menar, att spatserandet först kommer att återvinna sitt anseende, när någon påvisar nyttiga effekter därav, såsom $\mathrm{t}$ ex att spatserandet förändrar stressade typ A personligheter till avslappade B-typer. Eller att även måttliga spatserturer höjer HDL-kolesterol alternativt ökar aerobisk kapacitet.

Veisrub kommer möjligen att bli bönhörd. I Journal of Sports Medicine 1980 beskriver Penny \& Rust hur ett promenad-jogging program påverkar personligheten hos medelålders kvinnor, som började med att promenera $2,5 \mathrm{~km} / \mathrm{dag}$. Skillnaderna jämfört med kontroller var små; dock menade

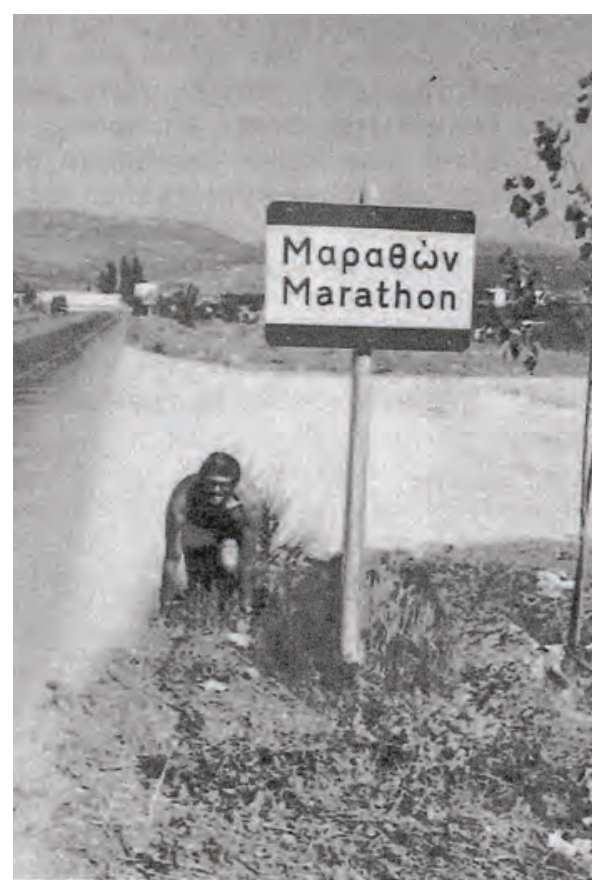

Författaren på väg. .

sig författarna kunna påvisa, att de promenerande damerna upplevde en högre grad av tillfredsställelse, accepterade sig själva bättre och kände sig mera avspända. Därmed synes denna viktiga fråga äntligen vara vetenskapligt bearbetad.

Vad beträffar möjliga vådor för reproduktionsapparaten av joggning har intet främkommit vid sökningen. Ett djurexperimentellt arbete föreligger dock. Hanekorrar sattes att springa i hjul, varvid man kunde konstatera en signifikant tillväxt av könsorganen jämfört med ekorrar, som inte fick löpa. I ett referat av artikeln stod försiktigt slutsatsen «dessa resultats betydelse för human fysisk aktivitet kan ännu ej utvärderas». Något ytterligare klarläggande i frågan har heller inte gått att få. 